University of Nebraska - Lincoln

DigitalCommons@University of Nebraska - Lincoln

$1-10-2000$

\title{
An efficient wheat transformation procedure: transformed calli with long-term morphogenic potential for plant regeneration
}

Lingyu Zhang

University of Nebraska-Lincoln

\section{J.J. Rybczynski}

The Botanical Garden-Center for Biological Diversity and Conservation of the Polish Academy of Sciences, PL-02-773 Warsaw, Poland

W.G. Langenberg

University of Nebraska-Lincoln

Amitava Mitra

University of Nebraska-Lincoln, amitra1@unl.edu

Roy C. French

University of Nebraska-Lincoln, rfrench2@unl.edu

Follow this and additional works at: https://digitalcommons.unl.edu/plantpathpapers

Part of the Plant Pathology Commons

Zhang, Lingyu; Rybczynski, J.J.; Langenberg, W.G.; Mitra, Amitava; and French, Roy C., "An efficient wheat transformation procedure: transformed calli with long-term morphogenic potential for plant regeneration" (2000). Papers in Plant Pathology. 17.

https://digitalcommons.unl.edu/plantpathpapers/17

This Article is brought to you for free and open access by the Plant Pathology Department at DigitalCommons@University of Nebraska - Lincoln. It has been accepted for inclusion in Papers in Plant Pathology by an authorized administrator of DigitalCommons@University of Nebraska - Lincoln. 
L. Zhang $\cdot$ J.J. Rybczynski $\cdot$ W.G. Langenberg

A. Mitra $\cdot$ R. French

\section{An efficient wheat transformation procedure: transformed calli with long-term morphogenic potential for plant regeneration}

Received: 15 June 1998 / Revision received: 6 April 1999 / Accepted: 26 April 1999

\begin{abstract}
A method for producing large numbers of transgenic wheat plants has been developed. With this approach, an average of $9.7 \%$ of immature embryo explants were transformed and generated multiple selffertile, independently transformed plants. No untransformed plants, or escapes, were regenerated. This transformation procedure uses morphogenic calli derived from scutellum tissue of immature embryos of Triticum aestivum cv. Bobwhite co-bombarded with separate plasmids carrying a selectable marker gene (bar) and a gene of interest, respectively. Transformed wheat calli with a vigorous growth phenotype were obtained by extended culture on media containing $5.0 \mathrm{mg} / \mathrm{l}$ bialaphos. These calli retained morphogenic potential and were competent for plant regeneration for as long as 11 months. The bar gene and the gene of interest were co-expressed in T0 progeny plants. This wheat transformation protocol may facilitate quantitative production of multiple transgenic plants and significantly reduce the cost and labor otherwise required for screening out untransformed escapes.
\end{abstract}

Key words bar $\cdot$ Embryos · Microprojectile · Transgene $\cdot$ Wheat

Communicated by R. Gilbertson

L. Zhang · A. Mitra

Department of Plant Pathology and Center for Biotechnology, University of Nebraska, Lincoln, NE 68583-0722, USA

\section{J.J. Rybczynski}

The Botanical Garden-Center for Biological Diversity and Conservation of the Polish Academy of Sciences,

PL-02-773 Warsaw, Poland

W.G. Langenberg · R. French (凶)

USDA-ARS, 344 Keim Hall, University of Nebraska, Lincoln, NE 68683-0939, USA

e-mail: rfrench@unlinfo.unl.edu

Fax: +1-402-472-2853
Abbreviations 2,4-D:2,4-Dichlorophenoxyacetic acid · $C I$ medium: Callus induction medium $\cdot C I-B$ medium: CI medium containing the selection agent $\cdot G U S$ : $\beta$-Glucuronidase - MCS: Multiple cloning sites · MS medium: Murashige and Skoog medium - PAT: Phosphinothricin acetyl transferase $\cdot P C R$ :

Polymerase chain reaction $\cdot R G$ medium:

Regeneration medium $\cdot R G-B$ medium: RG medium containing the selection agent $\cdot R T$ medium: Rooting medium $\cdot R T-B$ medium: RT medium containing the selection agent $\cdot T 0$ : Transformed plants regenerated directly from callus line

\section{Introduction}

Recently, a number of advances have been made in the development and optimization of procedures for transformation of several monocot crops including wheat (Altpeter et al. 1996; Blechl and Anderson 1996; Barro et al. 1997; Cheng et al. 1997; Dobrzanska et al. 1997; Takumi and Shimada 1997). For practical use in breeding programs, a large number of independently transformed lines are desirable so that those with stable transgene integration and a high level of expression can be selected (Altpeter et al. 1996). The number of transformed plant lines can be increased either by improving the efficiency of transformation or by reducing the time required for their production (Altpeter et al. 1996). Transformation of monocots, however, is still inefficient (Barro et al. 1997; Cheng et al. 1997; Dobrzanska et al. 1997; Takumi and Shimada 1997). Most procedures, therefore, have focused on shortening the time frame for the production of transgenic plants (Altpeter et al. 1996; Blechl and Anderson 1996).

These procedures typically consist of inducing shortterm morphogenic callus from the epidermal or subepidermal cell layer of the scutellum of immature embryos (Maes et al. 1996). After bombardment, the embryos are kept on callus induction medium with no selection or with low selection (e.g., 1.0-3.0 mg/l bialaphos) for a 
short period (2-4 weeks) for production of embryoids. After this stage, plant regeneration is usually induced on medium containing none or a minimal level of auxin or a mixture of cytokinins and auxins (Altpeter et al. 1996). These manipulations generally produce many regenerants but few true transformants. The transformation efficiencies are usually $0.1-2.5 \%$ (Weeks et al. 1993; Nehra et al. 1994; Altpeter et al. 1996; Barro et al. 1997; Dobrzanska et al. 1997; Takumi and Shimada 1997). Using these methods, several hundred to thousands of immature embryos or explants are typically bombarded to obtain about ten transgenic T0 plants. Therefore, these high-throughput methods are less practical for use by laboratories where either labor or space is limited.

We describe here a method for producing a large number of transgenic wheat plants by increasing the overall transformation efficiency. This wheat transformation procedure consists of inducing long-term morphogenic callus from bombarded scutellum tissue maintained under a relatively high selection pressure $(5.0 \mathrm{mg} / \mathrm{l}$ of bialaphos). The calli were kept on the callus induction medium with this high selection for 2 months without subculturing. This selection pressure was applied immediately after the osmotic shock treatment and maintained until the rooting stage. With this method, $9.7 \%$ of the explants were transformed, which is about four- to tenfold higher than previously described methods. The majority $(65 \%)$ of the transformed callus lines produced multiple fertile transgenic plants without any escapes, and they remained morphogenic for up to 1 year. Thus, bioassays for bar gene expression are less critical with this transformation method. Expression of bar and a gene of interest, $r n c 70$ (a bacterial ribonuclease gene), is shown. Plant transformation efficiencies were increased while space and labor requirements were reduced. Thus, this procedure can be used for quantitative and long-term production of primary transgenic wheat plants.

\section{Materials and methods}

\section{Media}

The basic medium was a Murashige and Skoog (1962) (MS) medium supplemented with $100 \mathrm{mg} / \mathrm{l}$ each of vitamin B1 (Gibco), myo-inositol (Sigma), and casein hydrolysate (Sigma), $30 \mathrm{~g} / \mathrm{l}$ sucrose (Sigma), and $0.25 \%$ Phytagel (Sigma) as a solidifying agent. Callus induction (CI) medium was the basic medium plus 2,4-dichlorophenoxyacetic acid (2,4-D) (Sigma) at 1.0, 2.0, or $3.0 \mathrm{mg} / \mathrm{l}$. Osmotic shock medium was CI supplemented with $0.4 \mathrm{~m}$ mannitol (Sigma). Regeneration (RG) medium was the basic medium. Rooting (RT) medium was half-strength basic medium. For all media, the $\mathrm{pH}$ was adjusted to 5.8 before autoclaving.

\section{Target tissue}

Young caryopses from wheat (Triticum aestivum cv. Bobwhite) plants grown in a growth chamber $\left(20^{\circ} \mathrm{C} / 15^{\circ} \mathrm{C}\right.$ day/night temperature and $12 \mathrm{~h}$ photoperiod) were dissected from spikes $12-16$ days after anthesis and surface sterilized with $1.3 \%$ sodium hypochlorite containing $10 \%$ ethanol for 15 min followed by five washes with sterile distilled water. Immature embryos were isolated and cultured on CI medium with the scutellum side up for 5-7 days at $25^{\circ} \mathrm{C}$ in the dark. During this period, the scutellum of most embryos increased in size due to cell divisions in the epidermal and subepidermal layers. Only explants with this type of growth were bombarded.

\section{Plasmid construction and polymerase chain reaction (PCR)}

Plasmid pAHC25M was a deletion derivative from pAHC25 (Christensen and Quail 1996). pAHC25 was digested with BamHI and the larger of the two fragments $(5.5 \mathrm{~kb})$ was recircularized to form pAHC25M. pAHC25M contains the bar gene, encoding phosphinothricin acetyl transferase (PAT), under transcriptional control of the maize ubiquitin promoter and first intron, followed by the nos terminator from Agrobacterium tumefaciens T-DNA. An expression vector for monocots, pLZ03 (Fig. 1), was also derived from pAHC25 by digesting it with HindIII and inserting the 4.2-kb HindIII fragment into pUC118. The resulting plasmid was cleaved with Bam HI to remove the gus (uid A) gene from the plasmid, and the $5.2-\mathrm{kb}$ product was religated followed by insertion of the nos terminator along with multiple cloning sites (MCS) from pBlueScript KS + . Wheat streak mosaic virus coat protein gene ( $c p$ ), a mutant bacterial RNase III gene ( $r n c 70$ from plasmid pAM1551; Langenberg et al. 1997), and tobacco etch virus $\mathrm{P} 3$ gene $(P 3)$ were amplified by PCR with primers including restriction sites, according to the procedure described by Zhang et al. (1993). The annealing temperatures for PCR amplification of the selection marker gene and the three genes of interest were $63^{\circ} \mathrm{C}($ bar $), 61^{\circ} \mathrm{C}(c p), 70^{\circ} \mathrm{C}(r n c 70)$, and $60^{\circ} \mathrm{C}(P 3)$. The three genes of interest were independently inserted into pLZ03 at the SacII and KpnI sites of MCS, resulting in the recombinant plasmids pLZ11 containing the $c p$ gene, pLZ12 containing the $r n c 70$ gene, and pLZ14 containing the $P 3$ gene.

\section{Microprojectile bombardment}

Proliferating scutellum tissue of cultured immature embryos was bombarded (Vasil et al. 1992) with the Biolistic PDS-1000 He gene gun (BioRad, Hercules, Calif., USA). Microcarriers were

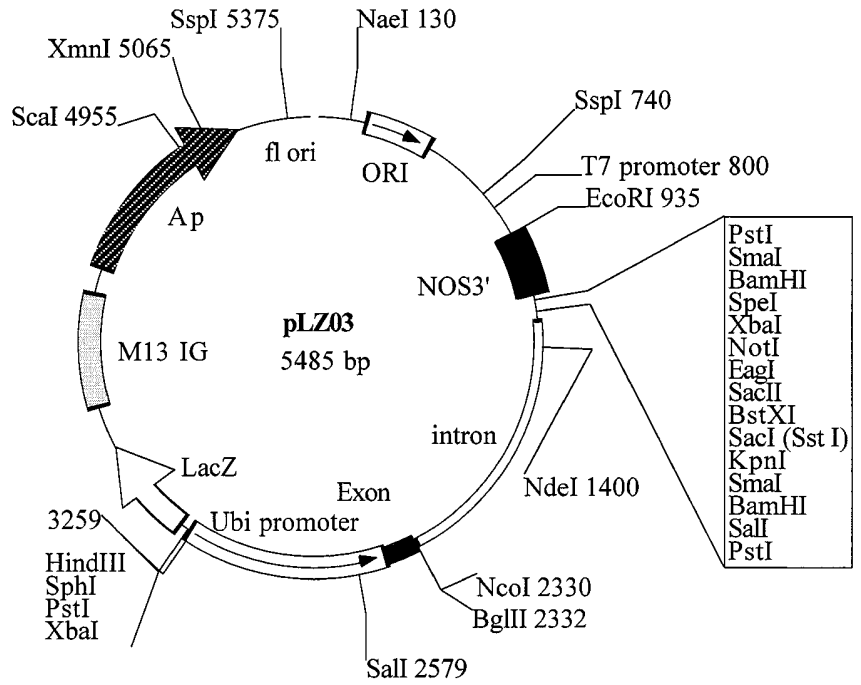

Fig. 1 Map of pLZ03, a monocot expression vector derived from pAHC25. A 4.2-kbHindIII fragment containing GUS and the ubiquitin promoter from $\mathrm{pAHC} 25$ was inserted into $\mathrm{pUC118}$. The GUS gene was removed from this plasmid at the BamHI sites, followed by insertion of the nos terminator along with multiple cloning sites from pBlueScript KS+ 
prepared as follows: $3 \mathrm{mg}$ gold $(1.0 \mu \mathrm{m})$ particles, suspended in $50 \mu \mathrm{l}$ distilled water, were mixed with $20 \mu \mathrm{g}$ DNA of pAHC25M and pLZ11 or pLZ12 or pLZ14 in a 1:1 molar ratio, followed by addition of $175 \mu \mathrm{l} \mathrm{CaCl} 2(2.5 \mathrm{~m})$ and $70 \mu \mathrm{l}$ spermidine $(0.1 \mathrm{~m})$. The mixture was gently vortexed for $10 \mathrm{~min}$ at room temperature and then centrifuged briefly. The gold particles were washed twice with $100 \%$ ethanol and resuspended in $100 \%$ ethanol $(50 \mu \mathrm{l})$. Fifteen microliters microcarrier suspension was used for each bombardment. Explants were placed on the osmotic shock medium for $4 \mathrm{~h}$ before bombardment (Vain et al. 1993). The distance from the stopping screen to the target was $10 \mathrm{~cm}$ and bombardment was at 1300 psi. Mock bombardment was done as the above procedure except that the microcarriers were not coated with plasmid DNA.

Selection of bialaphos-resistant callus lines and plant regeneration

To select for bar gene expression, two concentrations, 2.0 and $5.0 \mathrm{mg} / \mathrm{l}$, of the selective agent bialaphos (Shinyo Sangyo, Tokyo, Japan), were added to CI (CI-B) and RG (RG-B) media. After bombardment, explants were kept on the osmotic shock medium for 16-20 h (Vain et al. 1993), transferred to CI-B medium, and kept for 2 weeks in the dark for callus induction. All subsequent cultures were maintained with $12 \mathrm{~h}$ light and at $25^{\circ} \mathrm{C}$, except for the rooting step which was at $20^{\circ} \mathrm{C}$. Bombarded explants were transferred to CI-B medium immediately after osmotic shock treatment. After 2 months on the same CI-B plate without subculturing, the growing calli were divided into several pieces and then subcultured on new CI-B plates at 3- to 4-week intervals in the presence of $5.0 \mathrm{mg} / \mathrm{l}$ bialaphos. All subcultures from the same callus were labeled as the same callus line. When a fast-growing callus line appeared, half of the tissue was subcultured on CI-B and half was transferred to the RG-B medium. After 2-4 weeks on RG-B medium, developing plantlets were transferred to RT medium containing $1.0 \mathrm{mg} / \mathrm{l}$ bialaphos (RT-B). Finally, plantlets from RT-B medium were planted in peat and transferred to a growth chamber or greenhouse. To shorten seed maturation time, immature embryos from heads of T0 plants were excised and germinated on hormone-free MS medium without selection.

Genomic DNA isolation and Southern blot hybridization analysis

DNA from wheat calli and leaves was isolated with a Puregene DNA isolation kit (Centra Systems, Minneapolis, Minn.). The procedure from the manufacturer was followed except that three chloroform extractions preceded the isopropanol precipitation. A $20-\mu \mathrm{g}$ aliquot of DNA digested with EcoRI and BamHI to excise the bar, $c p$ and $r n c 70$ genes, or with $S s p$ I to determine the number of integration sites per genome was examined by electrophoresis in a $0.8 \%$ agarose gel. DNA from untransformed calli or plants served as negative controls. Positive controls were restriction digests of plasmids pAHC25M, pLZ11, or pLZ12. For PCR, transgenes were amplified from genomic DNA (0.1-0.4 $\mu \mathrm{g})$ using the same protocol as previously described. Digested genomic DNA or PCR-amplified fragments were examined on $0.8 \%$ agarose gels, blotted onto a membrane, and probed with DIGlabeled PCR products of the genes (DIG DNA Labeling and Detection Kit, Boehringer Mannheim, Indianapolis, Ill., USA).

\section{Western blot analysis}

Total proteins were isolated from calli and leaves using TriPure Isolation Reagent (Boehringer Mannheim) as described by the manufacturer. The Amplified Alkaline Phosphatase Goat AntiRabbit Immuno-Blot Assay Kit (BioRad) was used for all immunoblot assays. Protein concentrations in the extracts were quantified by the Bradford method (Bradford 1976). Extracts, containing $5 \mu \mathrm{g}$ of total soluble proteins, were separated on $12 \%$ acrylamide gels. Positive controls were $100 \mathrm{ng}$ purified bacterial RNase III or PAT proteins. The rabbit polyclonal antibodies against RNase III (gift from Dr. D. L. Court, NCI-Frederick Cancer Research and Development Center, Frederick, Md.) or PAT (courtesy of Drs. R. Shillito and L. Huang, AgrEvo) were used at $1: 1000$ dilution.

\section{Herbicide application}

Liberty (AgrEvo, Wilmington, De.), a commercial formulation of phosphinothricin, contains $182 \mathrm{~g} / \mathrm{l}$ of avtive ingredient. An aqueous solution containing $2 \%$ ( $\mathrm{vol} / \mathrm{vol})$ of Liberty was applied with a cotton-tipped applicator to the leaves of T0 and untransformed control plants at the two- to four-leaf-stage. The plants were then observed over a 17-day period.

\section{Results and discussion}

\section{Effect of 2,4-D in CI medium on formation of embryogenic callus}

The degree of cellular organization and shoot meristems in most wheat genotypes can be controlled by manipulation of 2,4-D concentrations (Sears and Deckard 1982). Different concentrations (from 0.5 to $8.0 \mathrm{mg} / \mathrm{l}$ ) of 2,4-D in wheat callus induction media have been reported (Ozias-Akins and Vasil 1982, 1983; Sears and Deckard 1982; Ou et al. 1989; Mohmand and Nabors 1990, 1991; Vasil et al. 1992; Vasil et al. 1993; Weeks et al. 1993; Nehra et al. 1994; Fellers et al. 1995; Altpeter et al. 1996; Maes et al. 1996; Dobrzanska et al. 1997). For the most part, these studies indicate that 2,4D concentrations of $1.0-2.0 \mathrm{mg} / \mathrm{l}$ are optimum to induce embryogenic callus from scutellum tissue of immature embryos. Therefore, we first examined the effects of three 2,4-D concentrations $(1.0,2.0$, and $3.0 \mathrm{mg} / \mathrm{l})$ on the development of embryogenic callus from wheat scutellum tissue in our culture conditions. These concentrations of 2,4-D in CI medium resulted in significantly different responses from explants after 15 days of culture. There was an obvious trade-off between callus growth and embryogenic potential of the cultured tissues at the different 2,4-D concentrations. At $1.0 \mathrm{mg} / \mathrm{l}$, about $95 \%$ of the explants responded by direct production or generation of somatic embryos, whereas growth of callus tissue was limited. In contrast, $3.0 \mathrm{mg} / \mathrm{l}$ of 2,4-D stimulated callus proliferation, but with a reduced embryogenic response $(34 \%)$. In the presence of $2.0 \mathrm{mg} / \mathrm{l}$ of 2,4-D, the number of embryogenic explants was $50 \%$ and callus proliferated well. Ozias-Akins and Vasil (1982) evaluated the effect of 2,4-D concentrations ranging from 1 to $8 \mathrm{mg} / \mathrm{l}$ on scutellar callus growth and found that a similar concentration of 2,4-D $(2 \mathrm{mg} / \mathrm{l})$ was optimal. Therefore, $2.0 \mathrm{mg} / \mathrm{l}$ of $2,4-\mathrm{D}$ was chosen for the subsequent transformation experiments. This concentration represents a compromise between cell proliferation and morphogenic potential. 
Selection of bialaphos-resistant callus lines and morphogenic competence of bombarded tissues

On CI-B plates containing $2.0 \mathrm{mg} / \mathrm{l}$ bialaphos, there was no significant inhibition of the growth and differentiation of mock-bombarded explants (i.e., explants bombarded with gold particles without coated DNA) compared with explants bombarded with pAHC25M within the first 2 months of culture on CI-B medium. However, a concentration of $5.0 \mathrm{mg} / \mathrm{l}$ of bialaphos in CI-B medium effectively inhibited cell growth of all mock-bombarded explants by 2 months of initial culture and such callus tissues became soft and watery (Fig. 2a). The pAHC25M-bombarded explants continued to grow and a proportion of these explants also exhibited a distinctive growth response exemplified by accelerated cell proliferation and vigorous callus growth (Fig. 2b, c). Therefore, a minimum period of 2 months culture on CI-B medium containing $5.0 \mathrm{mg} /$ 1 bialaphos, before regeneration, was used for the subsequent transformation experiments. A total of 32 callus lines with the robust, fully bialaphos resistant phenotype described above were obtained from four separate bombardment experiments using three different combinations of co-transformations (Table 1). In two experiments, the gene of interest was $r n c 70$ and in the other two experiments one was $c p$ and the other was $P 3$. These lines were obtained between 6 weeks to 4 months after initial selection on CI-B medium. Among the 32 bialaphos-resistant callus lines, a few showed white compact callus tissues but did not develop organized structures (Fig. 2b). These lines (D1, D2, D5, D14, D16, I1, and I11) were not morphogenic and did not produce any shoots or roots after transfer onto RG-B medium (Table 1). Most callus lines contained yellowish clusters of embryogenic cells, which showed the characteristically compact and nodular appearance (Fig. 2c, d) described by OziasAkins and Vasil (1982) and Redway et al. (1990). Somatic embryos that developed from these embryogenic cell clusters gave rise to coleoptile structures (Fig. 2d). Because a bialaphos-resistant callus line consists entirely of bialaphos-resistant callus tissues derived from a single explant, the collection of growing cells could be derived from a single cell or could be the progeny of multiple initially transformed cells.

Bialaphos, used in our experiments as the selective agent, is the active ingredient of the herbicide Basta,

Table 1 Regeneration of bialaphos-resistant callus lines

\begin{tabular}{|c|c|c|c|c|c|c|}
\hline Experiment & $\begin{array}{l}\text { Constructs for } \\
\text { co-transformation }\end{array}$ & $\begin{array}{l}\text { Number of explants } \\
\text { (embryos) } \\
\text { bombarded }\end{array}$ & $\begin{array}{l}\text { Name of resistant } \\
\text { callus lines }\end{array}$ & $\begin{array}{l}\text { Transformation } \\
\text { efficiency }^{\mathrm{a}} \\
(\%)\end{array}$ & $\begin{array}{l}\text { Number of T0 } \\
\text { plants }\end{array}$ & $\begin{array}{l}\text { Regenerable } \\
\text { callus line }{ }^{\mathrm{b}} \\
(\%)\end{array}$ \\
\hline 1 & pAHC25MpLZ12 & 22 & $\begin{array}{l}\text { B1 } \\
\text { B2 } \\
\text { B3 }\end{array}$ & $13.6 \%$ & $\begin{array}{l}3 \\
\text { Only roots } \\
2\end{array}$ & 66 \\
\hline 2 & 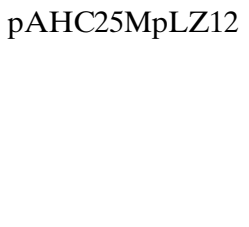 & 195 & $\begin{array}{l}\mathrm{C} 1 \\
\mathrm{C} 2 \\
\mathrm{C} 3 \\
\mathrm{C} 4 \\
\mathrm{C} 5 \\
\mathrm{C} 6 \\
\mathrm{C} 7\end{array}$ & $3.6 \%$ & $\begin{array}{l}10 \\
5 \\
28 \\
16 \\
22 \\
11 \\
\text { Contaminated }\end{array}$ & 100 \\
\hline 3 & pAHC25MpLZ11 & 136 & $\begin{array}{l}\text { D1 } \\
\text { D2 } \\
\text { D3 } \\
\text { D4 } \\
\text { D5 } \\
\text { D6 } \\
\text { D7 } \\
\text { D8 } \\
\text { D9 } \\
\text { D10 } \\
\text { D11 } \\
\text { D12 } \\
\text { D13 } \\
\text { D14 } \\
\text { D15 } \\
\text { D16 }\end{array}$ & $11.8 \%$ & $\begin{array}{l}0 \\
0 \\
20 \\
40 \text { (2 albinos) } \\
0 \\
3 \\
2 \\
4 \text { (all albinos) } \\
20 \\
12 \\
\text { Contaminated } \\
13 \\
2 \\
0 \\
2 \\
0\end{array}$ & 67 \\
\hline 4 & pAHC25MpLZ14 & 60 & $\begin{array}{l}\text { I1 } \\
\text { I4 } \\
\text { I6 } \\
\text { I7 } \\
\text { I9 } \\
\text { I11 }\end{array}$ & $10.0 \%$ & $\begin{array}{l}0 \\
8 \\
\text { Only roots } \\
9 \\
28 \\
0\end{array}$ & 50 \\
\hline
\end{tabular}

\footnotetext{
a Percent bombarded embryos giving rise to herbicide-resitant callus
}

b Percent resitant callus lines giving rise to transformed plants = fraction of resistant callus lines that produced at least one T0 plant 

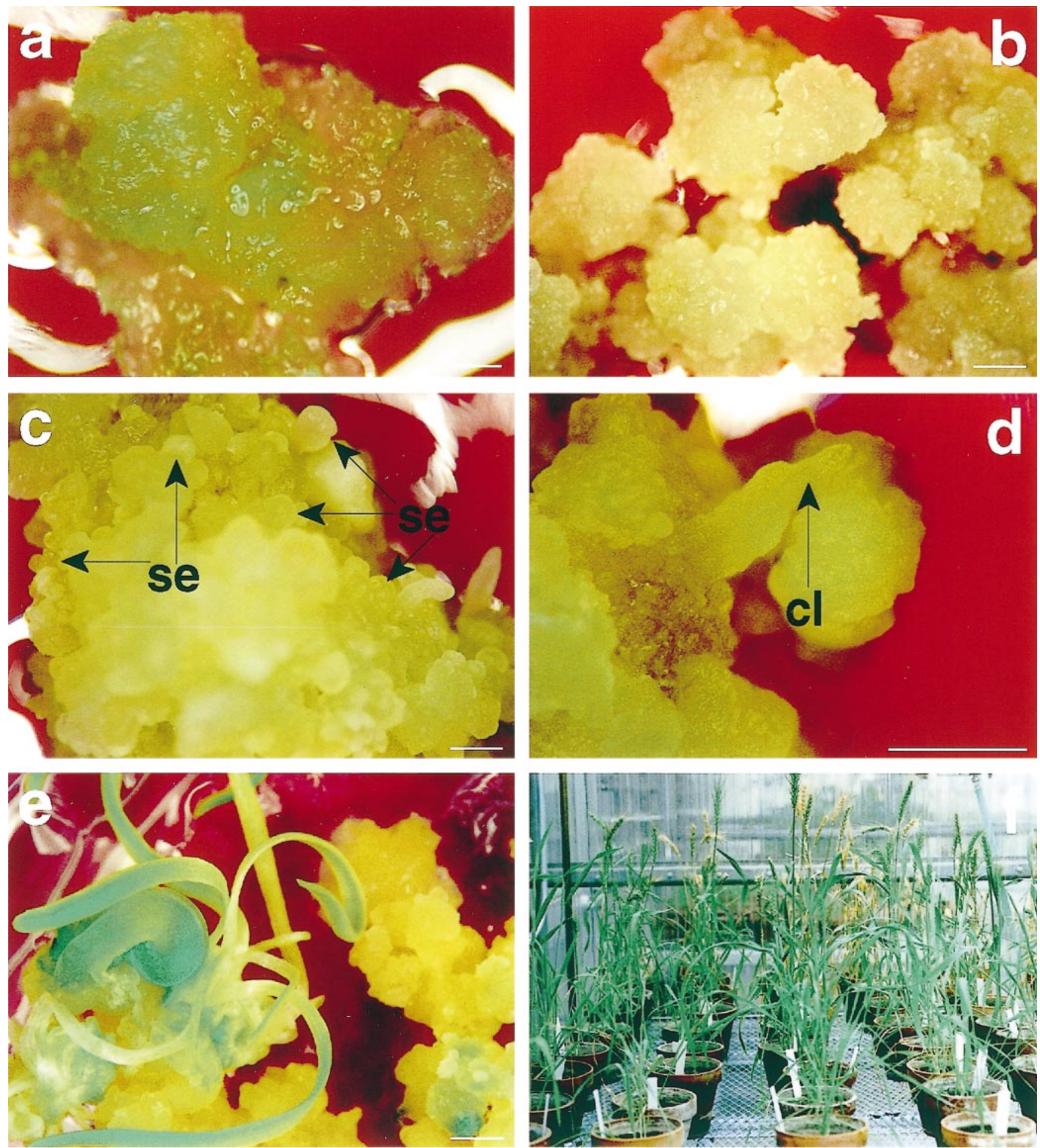

Fig. 2a-f Bialaphos selection $(5.0 \mathrm{mg} / \mathrm{l})$ and plant regeneration from bombarded calli. a A bialaphos-susceptible callus after 2 months culture on a CI-B plate, showing soft and watery tissues (bar $2 \mathrm{~mm}$ ). b A bialaphos-resistant and non-morphogenic callus line on a CI-B plate 2 weeks after transfer (11 months after bombardment). The callus tissues were off-white, compact, and lacked organized structures (bar $2 \mathrm{~mm}$ ). c, d Bialaphos-resistant

and morphogenic callus lines on CI-B plates 2 weeks after transfer (11 months after bombardment). These callus tissues contained somatic embryos (se) at various stages of development and a coleoptile $(c l)$ (bars $2 \mathrm{~mm}$ ). e Regeneration of T0 plants from callus lines. Green-shoot formation can be seen on RG-B plates 2-3 weeks after transfer from CI-B plates (11 months after bombardment) (bar $2 \mathrm{~mm}$ ). f T0 plants in a greenhouse 
and inhibits glutamine synthetase (Tachibana and Kaneko 1986; Tachibana et al. 1986a) resulting in slow cell death due to ammonia accumulation (Tachibana et al. 1986b). However, the concentrations of bialaphos commonly used during the callus induction stage $(1.0-3.0 \mathrm{mg} / \mathrm{l})$ do not effectively inhibit non-transformed calli, at least within 2-4 weeks of culture (Weeks et al. 1993; Altpeter et al. 1996), which results in numerous non-transformed plants. Altpeter et al. (1996) and Karunaratne et al. (1996) applied a high selection pressure, $5.0 \mathrm{mg} / \mathrm{l}$ of bialaphos, in shoot and root induction stages, but not in the callus induction stage. This later application of high bialaphos selection $(5.0 \mathrm{mg} / \mathrm{l})$ is apparently not effective in eliminating untransformed escapes, because Altpeter's group reported escape rates ranging from 55 to $88 \%$ (Altpeter et al. 1996). In our four independent experiments, the bombarded explants were subjected to $5.0 \mathrm{mg} / \mathrm{l}$ of bialaphos selection immediately after the osmotic shock treatment. This earlier exposure of bombarded explants to the high bialaphos selection, together with the subsequent 2-month culture under this high selection pressure appeared to reduce greatly the number of surviving untransformed calli and, thus, escape plants. Molecular analyses (PCR, Southern and Western) of 33 regenerants from three co-transformations showed that all contained and expressed the bar gene (Table 2). Thus, this strategy may make it unnecessary to use herbicide selection of T0 plants to eliminate untransformed escapes.

Selection pressures of 5.0 and $10.0 \mathrm{mg} / \mathrm{l}$ of bialaphos have been reported in transformation of barley (Wan and Lemaux 1994), rice (Toki et al. 1992), and maize (Brettschneider et al. 1997). Our selection approach is similar to that reported by Wan and Lemaux (1994) for barley transformation.

Most bialaphos-resistant callus lines retained their morphogenic potential for at least 11 months after the initial culture. While long-term morphogenic capacity has been reported for untransformed scutellum-derived callus from several wheat genotypes (Redway et al. 1990; Sears and Deckard 1982; Vasil et al. 1992), this is the first report of such morphogenic competence for transformed callus culture.

Plant regeneration, albinism, and fertility

Thirty surviving bialaphos-resistant callus lines from four bombardment experiments shown in Table 1 were

Table 2 Transmission of the transgenes (+ present, - absent) from calli to T0 plants

\begin{tabular}{|c|c|c|c|c|c|}
\hline Name of callus line & bar gene ${ }^{a}$ & Gene of interest ${ }^{a}$ & T0 plant & bar gene & Gene of interest \\
\hline $\mathrm{C} 1$ & + & + & $\begin{array}{l}\mathrm{C} 1-1 \\
\mathrm{C} 1-2 \\
\mathrm{C} 1-3 \\
\mathrm{C} 1-6 \\
\mathrm{C} 1-7 \\
\mathrm{C} 1-8\end{array}$ & $\begin{array}{l}+ \\
+ \\
+ \\
+ \\
+ \\
+\end{array}$ & $\begin{array}{l}+ \\
+ \\
+ \\
+ \\
+ \\
+\end{array}$ \\
\hline C3 & + & + & $\begin{array}{l}\text { C3-1 } \\
\text { C3-2 }\end{array}$ & $\begin{array}{l}+ \\
+\end{array}$ & $\begin{array}{l}+ \\
+\end{array}$ \\
\hline C5 & + & + & $\begin{array}{l}\text { C5-1 } \\
\text { C5-2 }\end{array}$ & $\begin{array}{l}+ \\
+\end{array}$ & $\begin{array}{l}+ \\
+\end{array}$ \\
\hline C6 & + & + & $\begin{array}{l}\text { C6-1 } \\
\text { C6-2 }\end{array}$ & $\begin{array}{l}+ \\
+\end{array}$ & $\begin{array}{l}+ \\
+\end{array}$ \\
\hline D4 & + & + & $\begin{array}{l}\text { D4-1 } \\
\text { D4-2 }\end{array}$ & $\begin{array}{l}+ \\
+\end{array}$ & $\begin{array}{l}- \\
-\end{array}$ \\
\hline D9 & + & + & $\begin{array}{l}\text { D9-1 } \\
\text { D9-2 } \\
\text { D9-3 } \\
\text { D9-4 }\end{array}$ & $\begin{array}{l}+ \\
+ \\
+ \\
+\end{array}$ & $\begin{array}{l}+ \\
+ \\
+ \\
+\end{array}$ \\
\hline D10 & + & + & D10-1 & + & + \\
\hline D12 & + & + & D12-1 & + & - \\
\hline I4 & + & + & $\begin{array}{l}\text { I4-1 } \\
\text { I4-2 }\end{array}$ & $\begin{array}{l}+ \\
+\end{array}$ & $\begin{array}{l}+ \\
+\end{array}$ \\
\hline I7 & + & + & $\begin{array}{l}\text { I7-1 } \\
\text { I7-2 } \\
\text { I7-3 }\end{array}$ & $\begin{array}{l}+ \\
+ \\
+\end{array}$ & $\begin{array}{l}- \\
- \\
-\end{array}$ \\
\hline I9 & + & - & $\begin{array}{l}\text { I9-1 } \\
\text { I9-2 } \\
\text { I9-3 } \\
\text { I9-4 } \\
\text { I9-5 } \\
\text { I9-6 } \\
\text { I9-7 } \\
\text { I9-8 }\end{array}$ & $\begin{array}{l}+ \\
+ \\
+ \\
+ \\
+ \\
+ \\
+ \\
+\end{array}$ & $\begin{array}{l}- \\
- \\
- \\
- \\
- \\
- \\
- \\
-\end{array}$ \\
\hline
\end{tabular}

\footnotetext{
a Confirmed by PCR, Southern or Western analysis
} 
periodically transferred to the RG-B medium under $5.0 \mathrm{mg} / \mathrm{l}$ bialaphos selection pressure and 21 of them (representing all co-transformations) retained morphogenic potential and yielded multiple regenerants during 11 months of subculture (Fig. 2e; Table 1). All regenerated shoots readily formed roots after transfer to RT-B medium. Plants regenerated from these callus lines grew to maturity in a greenhouse (Fig. 2f) and were fertile in many cases. Six albino plantlets arose from two callus lines (Table 1) and two lines (B2 and I6) generated only roots.

Plants regenerated over the months of subculture were able to flower. For example, fertility rates for those callus lines in experiment 4 ranged from sterile for $\mathrm{I} 7,50 \%$ for I 4 to $89 \%$ for I 9 , for an average of $46 \%$. Four plants regenerated from 15 -month-old callus lines (D4, D10, and D12) were also fertile. Loss of regeneration capacity, increase of albinism, and lack of fertility are usually associated with prolonged periods of cell/ callus culture (Fellers et al. 1995; Altpeter et al. 1996). Most transformed callus lines in this study, however, retained regeneration potential for 11 months and increased albinism and fertility problems were not correlated (Table 1). Sears and Deckard (1982) reported a similar situation for regenerated wheat plants with prolonged culture of 3- to 14-month-old untransformed scutellum-derived callus lines from 18 of 39 genotypes of winter wheat examined. Redway et al. (1990) also reported similar observations with scutellum-derived long-term morphogenic callus lines. The fertility rate of the transgenic wheat plants likely could be improved by cross-pollinating the non-selffertile plants with wild-type pollen as reported by Vasil et al. (1992) and Weeks et al. (1993).

\section{Herbicide application}

The herbicide Liberty was applied to $12 \mathrm{~T} 0$ plants carrying both bar and rnc70 genes and 10 untransformed control plants. All 12 T0 plants survived the herbicide application, whereas all control plants were dead by 17 days after herbicide application. This implies that the functional bar gene had been transmitted from calli to the T0 plants. These results are consistent with those in Table 2 and suggest that there were no untransformed escapes among the regenerated T0 plants.

DNA analysis of the bialaphos-resistant callus lines and T0 plants

The 30 surviving callus lines were further analyzed for integration of the bar, $c p, r n c 70$, or $P 3$ genes by PCR and Southern blot hybridization analysis. In addition, 12 T0 plants derived from four rnc70 callus lines, 8 from four $c p$ callus lines, and 13 from three $P 3$ callus lines were analyzed for transfer of the genes from the calli to regenerants. Genomic DNA from calli and T0 plants was digested with BamHI and EcoRI to release a $0.9-\mathrm{kb}$ fragment containing the bar gene and the nos terminator from pAHC $25 \mathrm{M}$, a $1.4-\mathrm{kb}$ fragment containing the $c p$ gene from pLZ11, a 0.7-kb fragment containing the $r n c 70$ gene from pLZ12, or a $1.2-\mathrm{kb}$ fragment containing the $P 3$ gene from pLZ14. All samples hybridized with the corresponding probe (Fig. 3a, b). The copy numbers of the transgenes were estimated by mixing plasmid DNA equivalent to one, five, or ten copies of the transgenes per wheat genome $\left(16 \times 10^{9} \mathrm{bp}\right.$; May and Appels 1987$)$ with $20 \mu \mathrm{g}$ total genomic DNA from non-transformed callus. For a single copy, $6.9 \mathrm{pg}$ of pAHC25M (bar), $8.6 \mathrm{pg}$ of pLZ11 $(c p), 7.7 \mathrm{pg}$ of pLZ12 ( $r n c 70)$, and $8.3 \mathrm{pg}$ of pLZ14 (P3) was used. The individual copy numbers of two genes from co-transformation were different in some callus lines (Fig. 3b). It should be noted that determination of copy number does not necessarily indicate the number of insertion loci. To analyze integration patterns, genomic DNA was also cleaved with SspI, which cleaves at a unique restriction site within the $r n c 70$ gene. The integration patterns varied among the lines (Fig. 3c). Distinct integration patterns also appeared in two T0 plants (C1-1 and C1-2) generated from the same callus line (C1). This difference between integration patterns could arise either from the products of different transformed cells or from chromosomal rearrangements during prolonged tissue culture. DNA extracted from non-transformed callus did not hybridize with any of the probes.

Western analysis of transgene expression in calli and plants

Western blots indicated that the selection marker gene, bar, was expressed in all callus lines, as expected because these callus lines grew vigorously under the high selection of bialaphos $(5 \mathrm{mg} / \mathrm{l})$. Western blots of protein extracts from each callus showed either a 26kDa (RNase III) or a 21-kDa (PAT) band (Fig. 4a). The level of expression ranged from 0.1 to $4 \%$ of total soluble proteins, as judged by relative band intensities of the samples compared to known amounts of purified proteins loaded onto the same gels (Fig. 4a). Both genes were also expressed in all T0 and T1 plants (Fig. 4b), indicating that both bar and $r n c 70$ genes were stably transmitted from calli to $\mathrm{T} 0$ and $\mathrm{T} 1$ progenies. The levels of expression varied among T0 plants (C1-1, C1-2, C1-6, and C1-7) generated from the same callus line, likely due to heterogeneity of the regenerants, transgene inactivation, or position effects of the transgenes. Two T1 progeny (C1-1-1 and C1-1-2) of the same T0 plant (C1-1) showed similar transgene expression levels. 
a

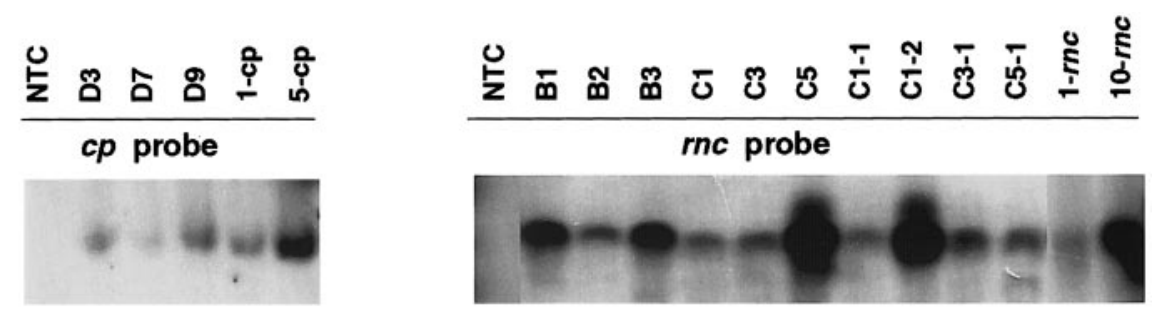

b
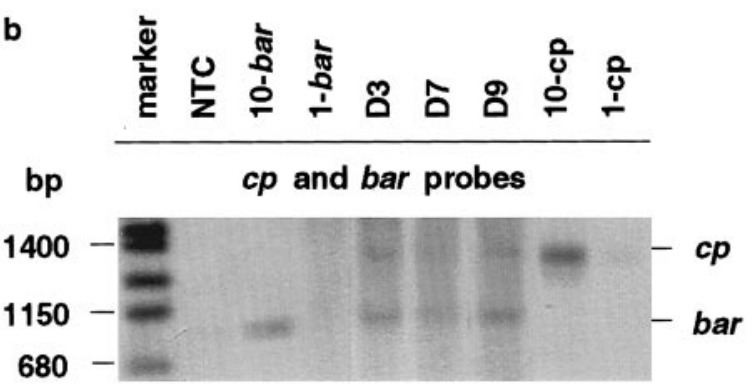

C

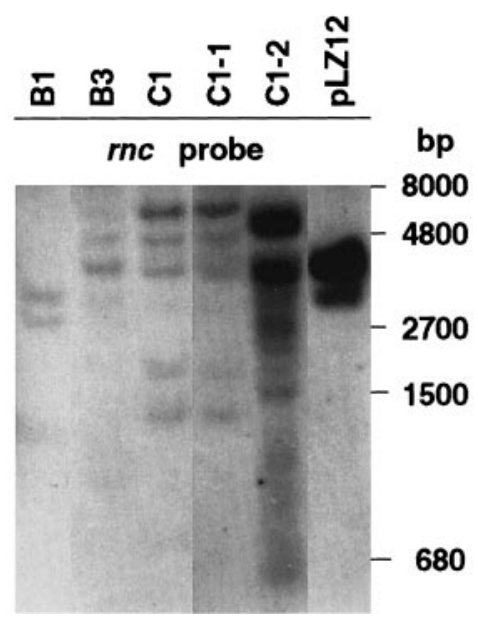

Fig. 3a-c Southern blot hybridization analysis of independent bialaphos-resistant callus lines and T0 plants. All blots were hybridized to DIG-labeled probes as indicated. Plasmid DNA representing one, five and ten copies of the introduced genes was mixed with BamHI- and EcoRI- digested genomic DNA from non-transformed callus (NTC). a Blot of BamHI- and EcoRIdigested genomic DNA (20 $\mathrm{g}$ /lane) from nine callus lines and four primary $\mathrm{T} 0$ plants showing hybridization of the probe for the gene of interest with total genomic DNA from all bialaphosresistant callus lines and T0 plants. b Blot of BamHI- and EcoRIdigested genomic DNA from callus lines exhibiting different copy numbers of the inserted genes from co-transformation. c Blot of SspI-digested genomic DNA from three callus lines and two T0 plants generated from callus line $\mathrm{C}-1$ displaying different integration patterns among the lines $(B 1, B 3$, and $C 1)$, between the callus $(C 1)$ and one of its T0 plants $(C 1-2)$, and between two T0 plants (C1-1 and $C 1-2)$ produced from the same callus line

Transformation, co-transformation, and co-expression efficiencies

Transformation efficiency of explants was calculated as the number of bialaphos-resistant callus lines over the total number of bombarded embryos (Table 1). All bialaphos-resistant callus tissues derived from a single explant were designated as one callus line. The explant transformation efficiencies of four independent experiments were $13.6,3.6,11.5$ and $10 \%$, with an average of $9.7 \%$. Sixty-five percent of these produced fertile T0 plants, giving a plant transformation efficiency of $6.3 \%$. We consider this a minimum transformation efficiency because the formula used in most published wheat transformation papers calculates transformation efficiency based upon the number of PAT-positive fertile plants divided by the number of bombarded embryos.

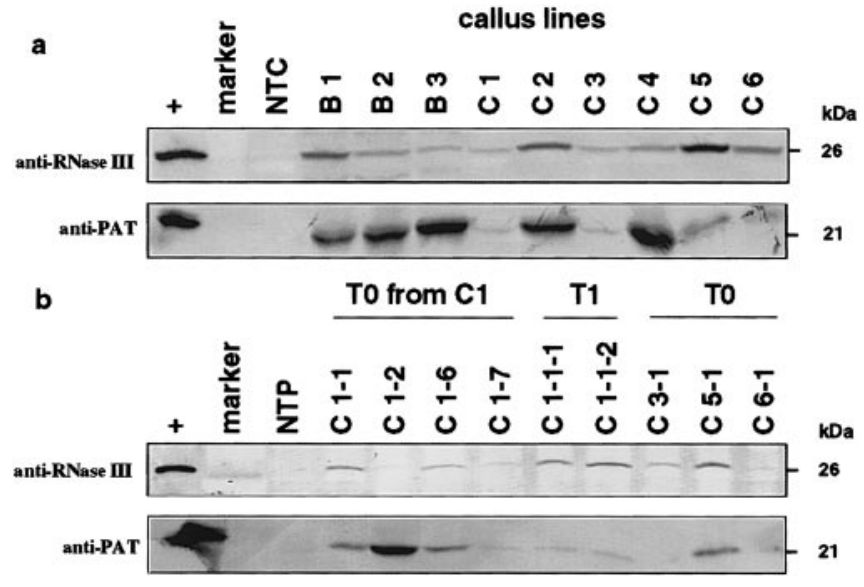

Fig. 4a,b Western blot analysis for the presence of RNase III and PAT in total proteins extracted from transformed calli and plants $(+$ a positive control of $100 \mathrm{ng}$ of purified RNase III or PAT protein). a Blot of transformed callus lines (NTC non-transformed callus). b Blot of T0 and T1 plants (C1-1,C1-2, C1-6 and C1-7 primary transformants (TO) of C1 callus line; $C 1-1-1$ and $C 1$ 1-2 progeny (T1) plants of $C 1-1 ; C 3-1, C 5-1$ and C6-1 primary transformants (TO) of $\mathrm{C} 3, \mathrm{C} 5$ and $\mathrm{C} 6$ callus lines, respectively; NTP non-transformed plant)

Using this calculation, an overall transformation efficiency of $28 \%$ was obtained with our protocol. Regardless, the minimum transformation efficiency $(6.3 \%)$ reported here is higher than those previously reported (0.1-2.5\%) (Weeks et al. 1993; Nehra et al. 1994; Altpeter et al. 1996; Barro et al. 1997; Cheng et al. 1997; Dobrzanska et al. 1997; Takumi and Shimada 1997). The higher transformation rates reported here are 
likely due to the induction of long-term morphogenic callus and the early application of high selection pressure. Most bialaphos-resistant calli became apparent only after 2 months of culture under a high selection pressure $(5.0 \mathrm{mg} / \mathrm{l}$ of bialaphos). Thus, a callus induction period of 2-4 weeks after bombardment may not provide enough time for most transformed cells to outgrow non-transformed ones, resulting in escapes and chimeric plants (Weeks et al. 1993; Nehra et al. 1994; Altpeter et al. 1996). Furthermore, the early application of the high selection pressure facilitated the growth of transformed cells by inhibiting growth of untransformed cells.

In our experiments, immature embryos were bombarded with two different plasmids, one carrying a selection marker gene and the other a gene of interest. Nineteen of $25 \mathrm{~T} 0$ plants regenerated from ten callus lines (all lines except I9 in Table 2) that were transformed with both bar and a gene of interest were found to have both genes, giving a co-transformation rate of $76 \%$. However, based on our limited data, there may be differences in co-transformation efficiency among different genes of interest used. For example, the rnc70 gene gave a $100 \%$ co-transformation efficiency whereas that of $c p$ was $62 \%$ and was only $40 \%$ for $P 3$.

Most recently published cereal transformation procedures using particle bombardment have relied on inducing short-term morphogenic callus from scutellum of immature embryos. Li et al. (1997) stressed that the availability of large amounts of uniform material for bombardment, with good morphogenic potential after repeated subculture and selection, is critical for successful transformation. It has been demonstrated that long-term morphogenic calli (3 months to 3 years) obtained from immature embryos of several genotypes of wheat have the potential to yield multiple fertile plants (Sears and Deckard 1982; Redway et al. 1990; Vasil et al. 1992). Vasil et al. (1992) showed that longterm (5- to 7-month-old) wheat callus culture, termed type $\mathrm{C}$ callus, can be used as an explant source for transformation and they obtained multiple fertile transformants, although the transformation efficiency was very low $(1 / 640)$.

In conclusion, we have explored the regeneration potential of long-term culture for improving wheat transformation efficiency by directly bombarding scutellum tissue of immature embryos and subsequently inducing long-term morphogenic callus from bombarded tissue under an immediate high selection pressure in a simple callus induction medium. We are unaware of previous reports on long-term culture of transformed wheat callus tissues that retain competence to produce self-fertile transgenic plants. This procedure reduces labor and time-consuming steps associated with explant isolation and culture, and may eliminate false-positive transformants and the need for herbicide application to select for transformed plants. This procedure should be applicable to other wheat cultivars with good embryogenic responses to callus induction media, such as some winter and spring cultivars reported by Ozias-Akins and Vasil (1982), Sears and Deckard (1982), Mohmand and Nabors (1990), Redway et al. (1990) and Maes et al. (1996).

Acknowledgments We thank Dr. Drake C. Stenger for assistance with figure graphics; Drs. Drake C. Stenger, Les. C. Lane, Troy J. Weeks, Allan Zipf and Thomas Clemente for comments on the original manuscript; Mr. Kyung-Moon Kim for helpful discussion on tissue culture; Dr. Alan H. Christensen for providing the plasmid pAHC25; Dr. D.L. Court for providing the RNase III gene, purified protein and antiserum; and Drs. R. Shillito and L. Huang (AgrEvo) for providing PAT protein and antiserum. J.J. Rybczynski wishes to thank the Fulbright Foundation for a senior research fellowship at the Department of Agronomy, University of Nebraska, Lincoln, Neb. Co-operative investigation of the USDA-ARS, and the Nebraska Agricultural Experiment Station. Published as paper no. 12181, Journal Series, Nebraska Agricultural Experiment Station. Mention of a trademark or proprietary product does not constitute a guarantee or warranty by the US Government and does not imply its approval to the exclusion of other products that may also be suitable.

\section{References}

Altpeter F, Vasil V, Srivastava V, Stoger E, Vasil IK (1996) Accelerated production of transgenic wheat (Triticum aestivum L.) plants. Plant Cell Rep 16:12-16

Barro F, Rooke L, Bekes F, Gras P, Tatham AS, Fido R, Lazzeri PA, Shewry PR, Barcelo P (1997) Transformation of wheat with high molecular weight subunit genes results in improved functional properties. Nat Biotechnol 15:1295-1299

Blechl AE, Anderson OD (1996) Expression of a novel highmolecular-weight glutenin subunit gene in transgenic wheat. Nat Biotechnol 14:875-879

Bradford M (1976) A rapid and sensitive method for the quantitation of microgram quantities of protein utilizing the principle of protein-dye binding. Anal Biochem 72:248-254

Brettschneider R, Becker D, Lorz H (1997) Efficient transformation of scutellar tissue of immature maize embryos. Theor Appl Genet 94:737-748

Cheng M, Fry JE, Pang S, Zhou H, Hironaka CM, Cuncan DR, Conner TW, Wan Y (1997) Genetic transformation of wheat mediated by Agrobacterium tumefaciens. Plant Physiol 115:971-980

Christensen AH, Quail PH (1996) Ubiquitin promoter-based vectors for high-level expression of selectable and/or screenable marker genes in monocotyledonous plants. Transgen Res 5:213-218

Dobrzanska M, Krysiak C, Kraszewska E (1997) Transient and stable transformation of wheat with preparations delivered by a biolistic method. Acta Physiol Plant 19:277-284

Fellers JP, Guenzi AC, Taliaferro CM (1995) Factors effecting the establishment and maintenance on embryogenic callus and suspension culture of wheat (Triticum aestivum L.). Plant Cell Rep 15:232-237

Karunaratne S, Sohn A, Mouradov A, Scott J, Steinbi H, Scott KJ (1996) Transformation of wheat with the gene encoding the coat protein of barley yellow mosaic virus. Aust J Plant Physiol 23:429-435

Langenberg WG, Zhang L, Court DL, Giunchedi L, Mitra A (1997) Transgenic tobacco plants expressing the bacterial $r n c$ gene resist virus infection. Mol Breed 3:391-399

Li Z, Upadhyaya M, Meena S, Gibbs AJ, Waterhouse PM (1997) Comparison of promoters and selectable marker genes for use in indica rice transformation. Mol Breed 3:1-14

Maes OC, Chibbar RN, Caswell K, Leung N, Kartha KK (1996) Somatic embryogenesis from isolated scutella of wheat: effects of physical, physiological and genetic factors. Plant Sci $121: 75-84$ 
May CE, Appels R (1987) The molecular genetics of wheat: toward an understanding of 16 billion base pairs of DNA. In: Heyne EG (ed) Wheat and wheat improvement. American Society of Agronomy, Madison, Wisc, p 165

Mohmand AS, Nabors MW (1990) Somaclonal variant plants of wheat derived from mature embryo explants of three genotypes. Plant Cell Rep 8:558-560

Mohmand AS, Nabors MW (1991) Comparison of two methods for callus culture and plant regeneration in wheat (Triticum aestivum). Plant Cell Tissue Organ Cult 26:187-189

Murashige T, Skoog F (1962) A revised medium for rapid growth and bioassays with tobacco tissue cultures. Physiol Plant $15: 473-497$

Nehra NS, Chibbar RN, Leung N, Caswell K, Mallard C, Steinhauer L, Baga M, Kartha KK (1994) Self-fertile transgenic wheat plants regenerated from isolated scutellar tissues following microprojectile bombardment with two distinct gene constructs. Plant J 5:285-297

Ou G, Wang WC, Nguyen HT (1989) Inheritance of somatic embryogenesis and organ regeneration from immature embryo cultures of winter wheat. Theor Appl Genet 78:137-142

Ozias-Akins P, Vasil IK (1982) Plant regeneration from cultured immature embryos and inflorescence of Triticum aestivum (wheat): evidence for somatic embryogenesis. Protoplasma 110:95-105

Ozias-Akins P, Vasil IK (1983) Improved efficiency and normalization of somatic embryogenesis in Triticum aestivum (wheat). Protoplasma 117:40-44

Redway FA, Vasil V, Lu D, Vasil IK (1990) Identification of callus types for long-term maintenance and regeneration from commercial cultivars of wheat (Triticum aestivum L.). Theor Appl Genet 79:609-617

Sears RG, Deckard EL (1982) Tissue culture variability in wheat: callus induction and plant regeneration. Crop Sci 22:546-550

Tachibana K, Kaneko K (1986) Development of new herbicide, bialaphos. J Pestic Sci 11:297-304
Tachibana K, Watanabe T, Sakizawa Y, Takematsu T (1986a) Inhibition of glutamine synthetase and quantitative changes of tree amino acids in shoots of bialaphos-treated Japanese barnyard millet. J Pestic Sci 11:27-31

Tachibana K, Watanabe T, Sakizawa Y, Takematsu T (1986b) Accumulation of ammonia in plants treated with bialaphos. $\mathbf{J}$ Pestic Sci 11:33-37

Takumi S, Shimada T (1997) Variation in transformation efficiencies among six common wheat cultivars through particle bombardment of scutella tissues. Genes Genet Syst 72:63-69

Toki S, Takamatsu S, Nojiri C, Ooba S, Anzai H, Iwata M, Christensen AH, Quail PH, Uchimiya H (1992) Expression of a maize ubiquitin gene promoter-bar chimeric gene in transgenic rice plants. Plant Physiol 100:1503-1507

Vain P, McMullen MD, Finer JJ (1993) Osmotic treatment enhances particle bombardment-mediated transient and stable transformation of maize. Plant Cell Rep 12:84-88

Vasil V, Castillo AM, Fromm ME, Vasil IK (1992) Herbicide resistant fertile transgenic wheat plants obtained by microprojectile bombardment of regenerable embryogenic callus. Biotechnology 10:667-674

Vasil V, Srivastava V, Castillo AM, Fromm ME, Vasil IK (1993) Rapid production of transgenic wheat plants by direct bombardment of cultured immature embryos. Biotechnology $11: 1553-1558$

Wan Y, Lemaux PG (1994) Generation of large numbers of independently transformed fertile barley plants. Plant Physiol. 104:37-48

Weeks JT, Anderson OD, Blechl AE (1993) Rapid production of multiple independent lines of fertile transgenic wheat (Triticum aestivum). Plant Physiol 102:1077-1084

Zhang L, French R, Langenberg WG (1993) Molecular cloning and sequencing of the coat protein gene of a Nebraskan isolate of tobacco necrosis virus: the deduced coat protein sequence has only moderate homology with those of strain A and strain D. Arch Virol 132:291-305 